\title{
Conceptual Shield Design for Boron Neutron Capture Therapy Facility Using Monte Carlo N-Particle Extended Simulator with Kartini Research Reactor as Neutron Source
}

\author{
Afifah Hana Tsurayya ${ }^{1, *}$, Azzam Zukhrofani Iman ${ }^{1}$, R. Yosi Aprian Sari', Arief Fauzi ${ }^{2}$, and Gede Sutresna \\ Wijaya ${ }^{3}$ \\ ${ }^{1}$ Department of Physics, Faculty of Mathematics and Natural Sciences, Universitas Negeri Yogyakarta, Yogyakarta 55281, Indonesia \\ ${ }^{2}$ Department of Nuclear Engineering and Engineering Physics, Faculty of Engineering, Universitas Gadjah Mada, Yogyakarta 55281, \\ Indonesia \\ ${ }^{3}$ Center of Accelerator Science and Technology, National Nuclear Energy Agency, Yogyakarta 55281, Indonesia \\ *Corresponding author: afifahhnts@gmail.com
}

KEYWORDS

Aluminium

BNCT

MCNPX

Paraffin

Shield

\begin{abstract}
The research aims to measure the radiation dose rate over the radiation shielding which is made of paraffin and aluminium and to determine the best shield material for the safety of radiation workers. The examination used MCNP (Monte Carlo N-Particle) simulator to model the BNCT neutron source and the shield. The shield should reduce radiation to less than the dose limit of $10.42 \mu \mathrm{Sv} / \mathrm{h}$, which is assumed to be the most conservative limit when the duration of workers is $1920 \mathrm{~h}$. The first design resulted in a radiation dose rate which was still greater than the limit. Therefore, optimization was done by adding the lead on the outer part of the shield. After optimization by adding the lead with certain layers, the radiation dose rate decreased, with the largest dose being $57.60 \mu \mathrm{Sv} / \mathrm{h}$. Some locations over the limit could be overcome by other radiation protection aspects such as distance and time. The paraffin blocks were covered by aluminium to keep the shield structure. The lead was used to absorb the gamma ray which resulted from the interaction between the neutrons and aluminium.
\end{abstract}

(c) The Author(s) 2018. This article is distributed under a Creative Commons Attribution-ShareAlike 4.0 International license.

\section{INTRODUCTION}

The World Health Organization (WHO) reported that 8.8 million people died due to cancer in 2015. Cancer treatments being used nowadays are chemotherapy, radiotherapy, and surgery (Benjamin 2014). The ineffectiveness of current cancer treatment methods has motivated some researchers to upgrade to advanced technology in cancer treatment (WHO 2017).

Boron Neutron Capture Therapy (BNCT) is a form of therapy that destroys specific cancer cells. BNCT uses nonradioactive nuclide ${ }^{10} \mathrm{~B}$ enriched compounds concentrated in cancer tissues that must be put into a patient's body. The cancer tissues are then irradiated by a low energy source from neutron beam which induces a nuclear reaction of ${ }^{10} \mathrm{~B}(\mathrm{n}, \alpha)^{7} \mathrm{Li}$. The length path of the particles is induced at a range of $4.5 \mu \mathrm{m}$ to $10 \mu \mathrm{m}$, approximately the diameter of a human cell. Thus, the probability of it reaching healthy cells is small. Japan, America, Finland, Argentina, and Taiwan are the countries which have used modified reactors for BNCT (Sauerwein and Moss 2009).

Shaaban and Albarhoum (2015) previously conducted research about improving the neutron flux for BNCT in the Syrian Miniature Neutron Source Reactor with the power of $30 \mathrm{~kW}$. It produces $2.53 \times 10^{15} \mathrm{n} / \mathrm{s}$, along with an epithermal flux of $2.83 \times 10^{8} \mathrm{n} / \mathrm{cm}^{2} \mathrm{~s}$. Mokhtari et al. (2017) have conducted research on LPMR (low power medical reactor) using fuel $\mathrm{U}_{3} \mathrm{Si}_{2}-\mathrm{Al}$. Their research encompassed in- creasing the epithermal flux by optimization, resulting in an epithermal flux of $1.01 \times 10^{9} \mathrm{n} / \mathrm{cm}^{2} \mathrm{~s}$.

Some Indonesian researchers have been exploring the possibility of BNCT for cancer treatment. BNCT research by in vitro and in vivo method has been done in Kartini Reactor, Yogyakarta. Kartini Reactor is TRIGA MARK-II reactor type with a thermal power of $100 \mathrm{~kW}$, to which it is planned that BNCT research facilities such as collimator and shield will be added. The collimator research was conducted by Warfi et al. (2016) in which optimization was by the design of Fauziah et al. (2015). The collimator is designed for the thermal column of the Kartini Reactor; it yields an epithermal neutron flux of $1.13 \times 10^{9} \mathrm{n} / \mathrm{cm}^{2} \mathrm{~s}$.

A BNCT research facility requires the shield to protect people from radiation. Radiation should be minimized in order to meet the requirements set up by BAPETEN (the Nuclear Energy Regulatory Agency of Indonesia) for safety reasons. The dose limit is based on BAPETEN regulations which explain that the dose limit for a radiation worker is $20 \mathrm{mSv} / \mathrm{y}$.

\section{MATERIALS AND METHODS}

\subsection{Experimental method}

The research is simulated using the Monte Carlo N-Particle Extended (MCNPX). MCNP is a computer code used to simulate the probability of neutron, photon, and electron as 


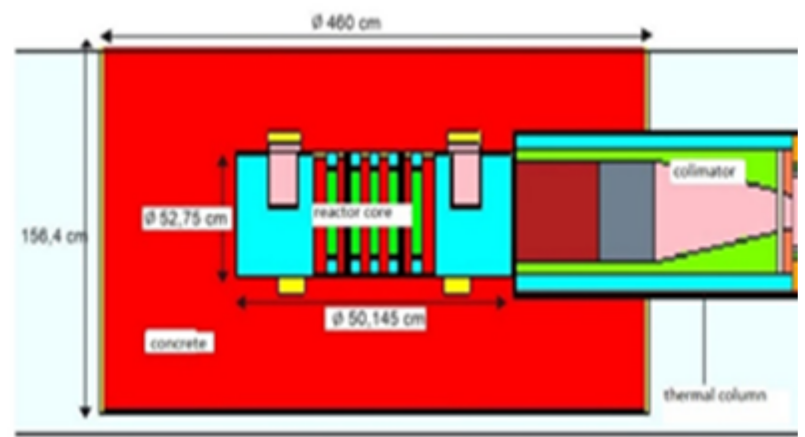

FIGURE 1. The collimator design by Warfi et al. (2016).

well as their interaction, including fission reaction, scattering, and absorption (Xoubi 2016).

The research is started by collecting data of BNCT facilities in Kartini Reactor. BATAN has designed the shield which is formed by paraffin blocks covered by aluminium with a thickness of $3 \mathrm{~mm}$. The dimension of each paraffin block with its aluminium cover is $(40 \times 40 \times 24) \mathrm{cm}$. The minimum effective dose used in this research is based on the recommendation of BAPETEN, and calculated using Equation 1:

\section{Working time:}

8 hours/day $\times 5$ days/week $\times 4$ weeks $/$ month

$$
\begin{aligned}
& \times 12 \text { months/year } \\
& =1920 \text { hours/year }
\end{aligned}
$$

The minimum dose can subsequently be calculated using Equation 2:

$$
\dot{\mathrm{H}}=20000 \frac{\mu S v}{\text { year }} \div 1920 \frac{\text { hours }}{\text { year }}=10.42 \frac{\mu S v}{\text { hour }}
$$

\subsection{Source modelling}

Kartini Reactor with the power of $100 \mathrm{~kW}$ is used for basic counting of multiplication factor. The number of fission reactions per second in Kartini Reactor is approximately given by Equation 3:

$$
\begin{aligned}
&\left(10^{5} \mathrm{~W}\right)\left(\frac{1 \frac{\mathrm{J}}{\text { second }}}{W}\right)\left(\frac{1 \mathrm{MeV}}{1.602 \times 10^{-13} \mathrm{~J}}\right)\left(\frac{1 \text { fission }}{200 \mathrm{MeV}}\right) \\
&=3.121 \times 10^{15} \text { fission } / \text { second }
\end{aligned}
$$

The result of Equation 3 is used to calculate the multiplication factor which will be input to the program. The counting multiplication factor is given in Equation 4.

$$
f m_{n}=\left(\frac{3.121 \times 10^{15} \text { fission }}{\text { seconds }}\right)\left(\frac{2.42 n}{\text { fission }}\right)=\frac{7.553 \times 10^{15} n}{\text { seconds }}
$$

For average 2.42 per fission rate, the normalization factor of neutron is as follows (Equation 5).

$$
f m_{y}=\left(\frac{3.121 \times 10^{15} \text { fission }}{\text { seconds }}\right)\left(\frac{1 y}{\text { fission }}\right)=\frac{3.121 \times 10^{15} y}{\text { seconds }}
$$

TABLE 1. The output of collimator by Warfi et al. (2016).

\begin{tabular}{lll}
\hline Parameter & Value & $\begin{array}{l}\text { Standard by IAEA (Sauerwein } \\
\text { and Moss 2009) }\end{array}$ \\
\hline$\Phi_{\text {epi }}\left(\mathrm{n} / \mathrm{cm}^{2} \mathrm{~s}\right)$ & $1.13 \times 10^{9}$ & $>1.00 \times 10^{9}$ \\
$\dot{D}_{y} / \Phi_{\text {epi }}\left(\mathrm{Gy} . \mathrm{cm}^{2} / \mathrm{n}\right)$ & $1.45 \times 10^{-13}$ & $<2.0 \times 10^{-13}$ \\
$\dot{D}_{f} / \Phi_{\text {epi }}\left(\mathrm{Gy} \cdot \mathrm{cm}^{2} / \mathrm{n}\right)$ & $1.76 \times 10^{-13}$ & $<2.0 \times 10^{-13}$ \\
$\Phi_{\text {th }} / \Phi_{\text {epi }}$ & 0.0108 & $<0.05$ \\
$J / \Phi_{\text {total }}$ & 0.75 & $>0.7$ \\
\hline
\end{tabular}

The modelling of Kartini Reactor and its collimator has been done by Warfi et al. (2016) (Figure 1). The collimator design is chosen because its output has met IAEA criteria. The output of collimator by Warfi et al. (2016) is shown in Table 1.

\subsection{Shield modelling}

The components of the shielding are paraffin and aluminium with the dimension of $(40 \times 40 \times 24) \mathrm{cm}$. The blocks formed were simulated by MCNPX and are shown in Figure 2.

\section{RESULTS AND DISCUSSION}

The dose rate is calculated in the soft tissue with the thickness of $5 \mathrm{~cm}$. The components of the soft tissue are published by ICRP (1999). The tally is F4 (flux average over a cell). A kerma coefficient is used to convert flux to become the dose with the unit of Gy/s. Then Gy/s is converted to $\mathrm{Sv} / \mathrm{s}$ by multiplying it with the weight factor for each radiation type.

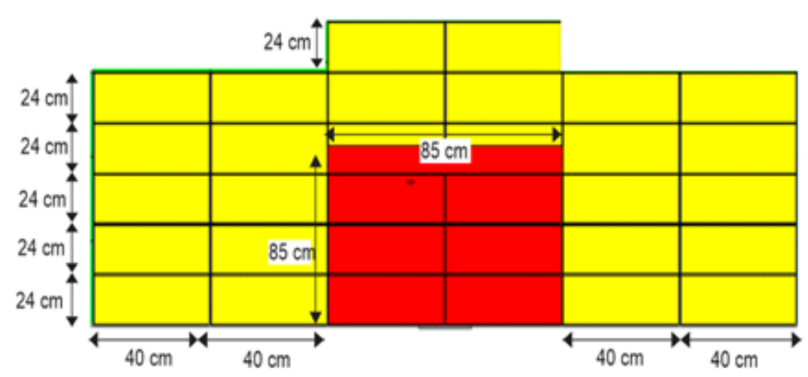

(a)

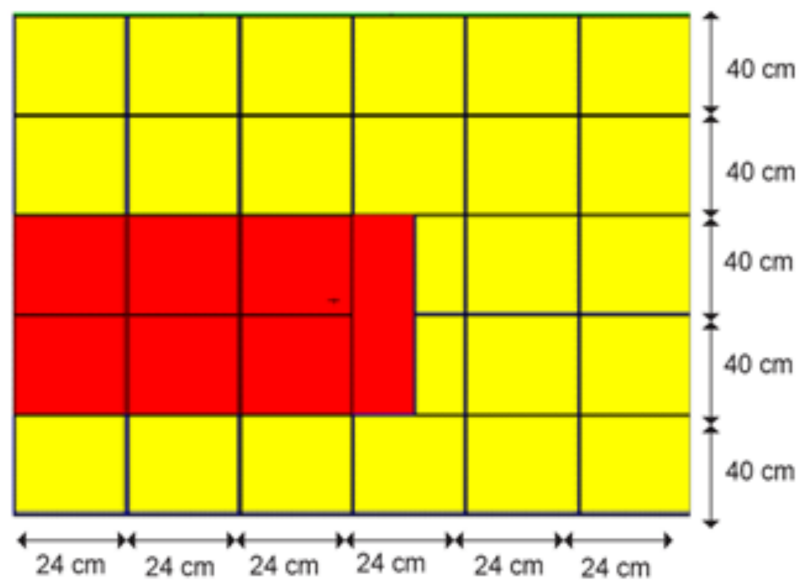

(b)

FIGURE 2. Shield model. (a) top view; (b) side view. 


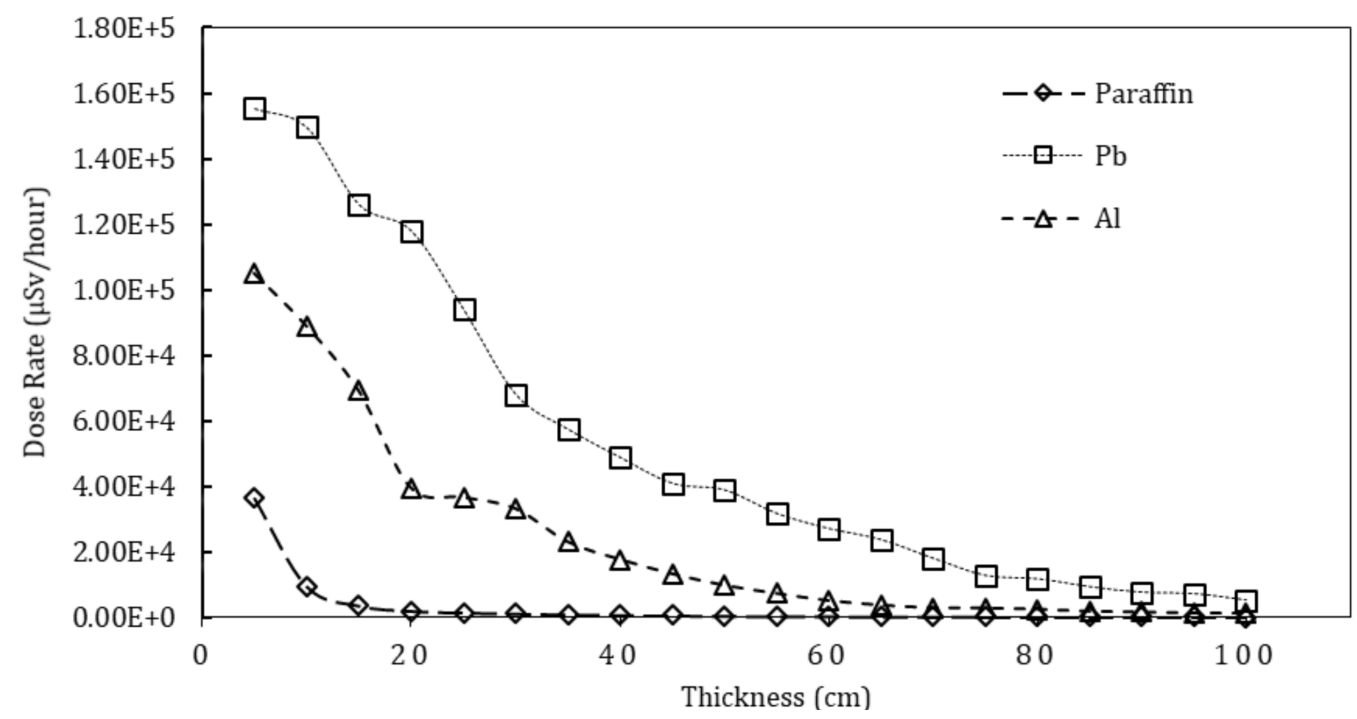

FIGURE 3. Dose rate for different thicknesses of materials suggested as shielding radiation.

TABLE 2. Shield dose rate in the left side.

\begin{tabular}{lllll}
\hline \multirow{2}{*}{ Soft tissue } & \multicolumn{3}{c}{ Dose rate $(\mu \mathrm{Sv} / \mathrm{h})$} \\
\cline { 3 - 5 } & & Initial & $\mathrm{Pb}$ & Final \\
\hline \multirow{2}{*}{ Left Center } & 1 & 108.36 & 3.50 & 26.26 \\
& 2 & 14.40 & - & 14.40 \\
Left Top & 1 & 95.09 & 0.70 & 14.26 \\
& 2 & 43.16 & 0.20 & 0.00 \\
& 3 & 2.58 & - & 2.58 \\
Left under & 1 & 2.14 & - & 2.14 \\
& 2 & 37.58 & 0.20 & 0.00 \\
& 3 & 102.24 & 0.20 & 0.00 \\
& 3 & 22.75 & - & 22.75 \\
\hline
\end{tabular}

TABLE 3. Shield dose rate in the right side.

\begin{tabular}{lllll}
\hline \multirow{2}{*}{ Soft tissue } & \multicolumn{3}{c}{ Dose rate $(\mu \mathrm{Sv} / \mathrm{h})$} \\
\cline { 3 - 5 } & & Initial & $\mathrm{Pb}$ & \multicolumn{1}{c}{ Final } \\
\hline \multirow{2}{*}{ Right center } & 1 & 82.08 & 2.40 & 3.24 \\
& 2 & 40.32 & 0.30 & 17.28 \\
Right top & 1 & 126.00 & 3.50 & 18.30 \\
& 3 & 21.97 & 2.50 & 18.30 \\
& 2 & 2.48 & - & 2.48 \\
Right under & 1 & 3.28 & - & 3.28 \\
& 3 & 146.80 & 3.30 & 0.00 \\
& 2 & 124.92 & 1.50 & 57.60 \\
& 3 & 48.60 & 0.20 & 13.86 \\
\hline
\end{tabular}

Soft tissue modeled in front of the collimator was used to calculate an initial dose of $45118.80 \mu \mathrm{Sv} / \mathrm{h}$. When calculating the dose rate over the shield, we modelled soft tissue in the surface. We tested the materials to compare each one's ability to reduce radiation, showing the dose rate when varying the thickness. The components were paraffin, aluminium, and lead. The results of the material testing is shown in Figure 3.

Paraffin is effective at absorbing the neutron because it contains hydrogen, but paraffin is not effective at absorbing gamma. Aygün and Budak (2012) found that the increase of

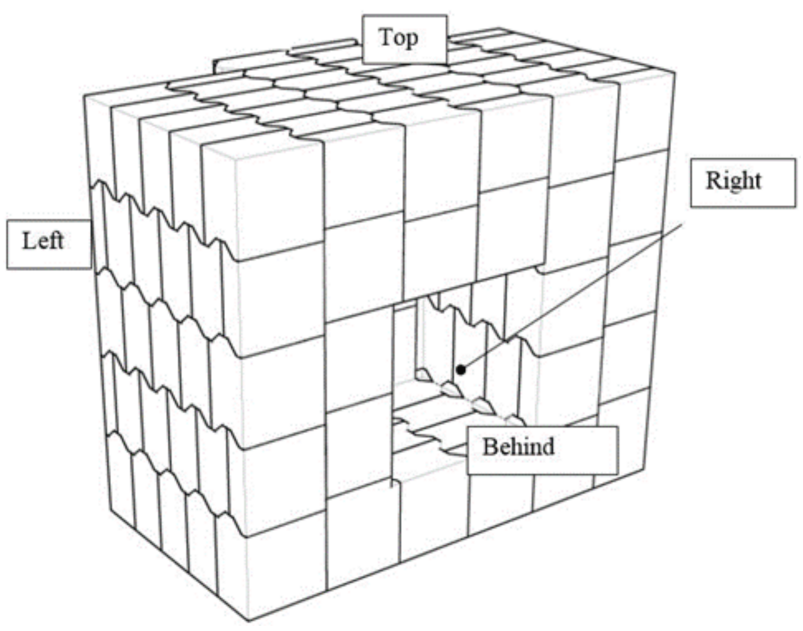

FIGURE 4. Shield design model.

oil concentration increases neutron shield. Jasim and Abdulameer (2014) found that paraffin material reduces the neutron energy. DiJulio et al. (2017) concluded on their research that the ability of concrete shield will increase when hydrogen is added. The attention should be focused on the shield for real conditions. However, since paraffin melts due to the heat, it is covered by aluminum to keep the structure of the paraffin. Aluminium has a high corrosive resistance because it has an oxide layer on its surface (Pokhmurskii et al. 2011).

The output of MCNPX yields that the gamma dose rate increases with the increase of aluminium thickness. Neutrons that strike aluminium produce gamma because of inelastic scattering that makes the nuclei of the material exited (Padalino et al. 1999). Lead has a high atomic number and high density making it effective in reducing gamma radiation (Zeb et al. 2010).

It is found that dose rate in some soft tissue model locations still have exceeded the dose limit of $10.42 \mu \mathrm{Sv} / \mathrm{h}$. This indicated that the high dose rate is coming from the gamma contamination. The interaction of neutrons with aluminium during the inelastic scattering process also contributes to producing gamma radiation. Then radiation shielding has been optimized by adding several lead layers in the outer surface of the shield (Figures 4 and 5). The 


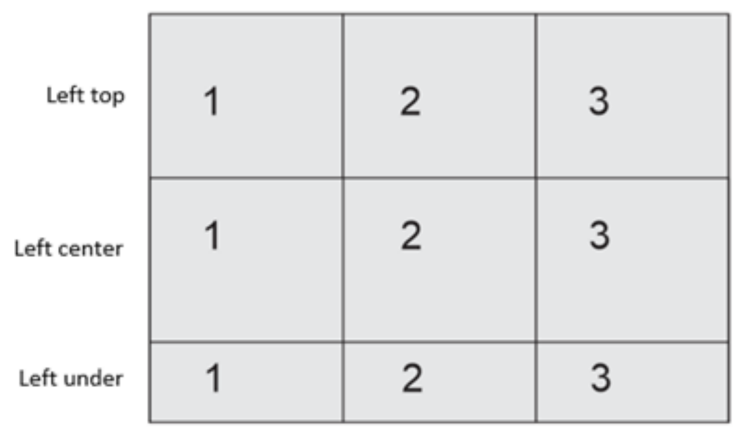

(a)

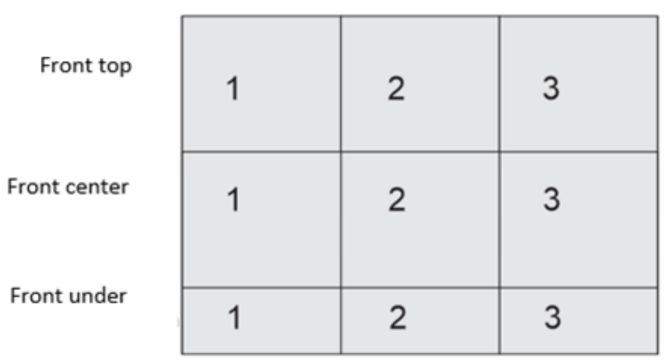

(c)

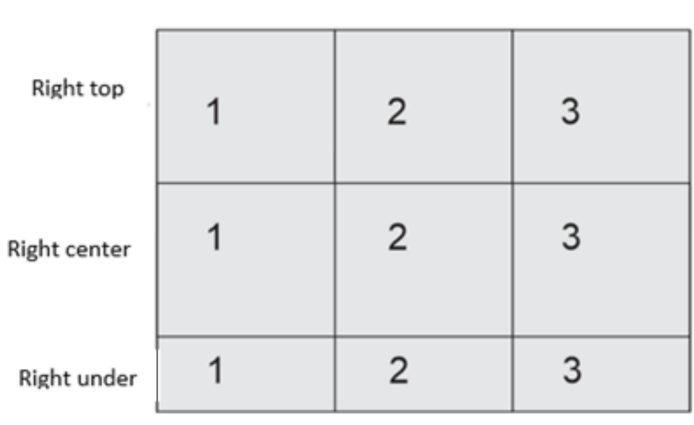

(b)

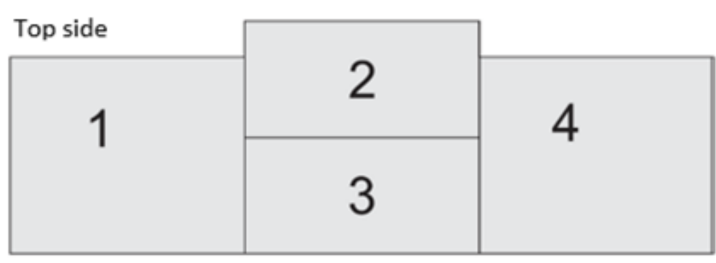

(d)

FIGURE 5. Soft tissue surface model: (a) left side; (b) right side; (c) front side; (d) top side.

TABLE 4. Shield dose rate in the front side.

\begin{tabular}{lllll}
\hline \multirow{2}{*}{ Soft tissue } & \multicolumn{3}{c}{ Dose rate $(\mu \mathrm{Sv} / \mathrm{h})$} \\
\cline { 3 - 5 } & & Initial & $\mathrm{Pb}$ & \multicolumn{1}{c}{ Final } \\
\hline \multirow{2}{*}{ Front center } & 1 & 720.00 & 9.00 & 12.60 \\
& 2 & 1251.00 & 9.50 & 9.36 \\
Front top & 1 & 745.20 & 12.00 & 12.96 \\
& 3 & 98.28 & 5.00 & 24.84 \\
& 2 & 284.04 & 6.50 & 3.08 \\
Front under & 1 & 73.33 & 4.50 & 23.40 \\
& 3 & 236.52 & 8.50 & 23.11 \\
& 2 & 1152.00 & 7.50 & 11.88 \\
& 3 & 205.20 & 4.00 & 9.72 \\
\hline
\end{tabular}

measured dose rates before and after being optimized are shown in Tables 2 to 5.

The largest dose rate is found in the front of shield because it is exactly in the front of the radiation source. Besides, the front side of shield is thinner than the others. From the tables are shown that dose rate has been reduced after optimization with lead with certain thickness. Some areas which are still above $10.42 \mu \mathrm{Sv} / \mathrm{h}$ can be solved by distance and time principle, since the flux is inversely proportional to the square of the distance, or $1 / r^{2}$ (Ahmed 2007). In the design, aluminium keeps the structure of the paraffin, and lead is useful to reduce gamma radiation which is produced by the inelastic scattering of the neutron and aluminium reaction. With consideration of economic aspect, the maximum thickness of lead in the front side is $12 \mathrm{~cm}$, the right side is $3.5 \mathrm{~cm}$, the left side is $3.5 \mathrm{~cm}$, and the top side is $2 \mathrm{~cm}$.

\section{CONCLUSIONS}

The shield has been optimized with lead and the results are obtained with the largest dose rate of $57.60 \mu \mathrm{Sv} / \mathrm{h}$. Alu-
TABLE 5. Shield dose rate in the top side.

\begin{tabular}{lllll}
\hline \multirow{2}{*}{ Soft tissue } & \multicolumn{3}{c}{ Dose rate $(\mu \mathrm{Sv} / \mathrm{h})$} \\
\cline { 3 - 5 } & & Initial & $\mathrm{Pb}$ & Final \\
\hline \multirow{2}{*}{ Top side } & 1 & 27.29 & 1.00 & 14.40 \\
& 2 & 37.49 & 0.30 & 8.64 \\
& 3 & 8.64 & - & 8.64 \\
& 4 & 20.27 & 2.00 & 11.59 \\
\hline
\end{tabular}

minium is applied in the design to keep the structure of the paraffin, while lead reduces gamma radiation which is produced by the inelastic scattering of the neutron and aluminium reaction.

\section{ACKNOWLEDGMENTS}

We would like to thank all members who supported this project. We would especially like to thank the Center for Accelerator Science and Technology (PSTA-BATAN) for the opportunities given to perform this work.

\section{REFERENCES}

Ahmed SN. 2007. Physics and engineering of radiation detection. Amsterdam: Academic Press.

Aygün B, Budak G. 2012. A new neutron absorber material: oil loaded paraffin wax. Nucl Sci Technol. 2012:33-39.

Benjamin DJ. 2014. The efficacy of surgical treatment of cancer - 20 years later. Med Hypotheses. 82(4):412-420. doi:10.1016/j.mehy.2014.01.004.

DiJulio D, Cooper-Jensen C, Perrey H, Fissum K, Rofors E, Scherzinger J, Bentley P. 2017. A polyethylene-B 4 C based concrete for enhanced neutron shielding at neutron research facilities. Nucl Instrum Methods Phys Res, Sect A. 859:41-46. doi:10.1016/j.nima.2017.03.064.

Fauziah N, Widiharto A, Sardjono Y. 2015. A conceptual design of neutron collimator in the thermal column of 
Kartini research reactor for in vitro and in vivo test of boron neutron capture therapy. J Nucl React Technol. 15(2):112-119.

[ICRP] International Commission Radiation Protection. 1999. Report of the Task Group on Reference Man. Technical report. ICRP Publication 23. Oxford: Pergamon Press.

Jasim MH, Abdulameer NT. 2014. Neutron capture cross section measurements of paraffin wax. Int J Appl Innov Eng Manag. 3:112-114.

Mokhtari J, Faghihi F, Khorsandi J, Hadad K. 2017. Conceptual design study of the low power and LEU medical reactor for BNCT using in-tank fission converter to increase epithermal flux. Prog Nucl Energy. 95:70-77. doi:10.1016/j.pnucene.2016.11.014.

Padalino S, Oliver H, Nyquist J. 1999. DT neutron yield measurement using neutron activation of aluminium. New York: The State University of New York.

Pokhmurskii V, Zin I, Vynar V, Bily L. 2011. Contradictory effect of chromate inhibitor on corrosive wear of aluminium alloy. Corros Sci. 53(3):904-908. doi:10.1016/j. corsci.2010.11.009.

Sauerwein WA, Moss RL. 2009. Requirements for boron neutron capture therapy (BNCT) at a nuclear research reactor. Technical report. Office for Official Publications of the European Communities. Luxembourg. doi: $10.2790 / 11743$.

Shaaban I, Albarhoum M. 2015. Design calculation of an epithermal neutronic beam for BNCT at the Syrian MNSR using the MCNP4c code. Prog Nucl Energy. 78:297-302. doi:10.1016/j.pnucene.2014.10.005.

Warfi R, Harto AW, Sardjono Y, Widarto W. 2016. Optimization of neutron collimator in the thermal column of Kartini research reactor for in vitro and in vivo trials facility of boron neutron capture therapy using MCNPX Simulator. Indones J Phys Nucl Appl. 1(1):54. doi: 10.24246/ijpna.v1i1.54-62.

[WHO] World Health Organization. 2017. The top 10 causes of death. [accessed 2017 Mar 29]. https://www.who.in $\mathrm{t} /$ news-room/fact-sheets/detail/the-top-10-caus es-of-death.

Xoubi N. 2016. Calculation of the power and absolute flux of a source driven subcritical assembly using Monte Carlo MCNP code. Ann Nucl Energy. 97:96-101. doi:10.1016/j. anucene.2016.07.009.

Zeb J, Arshad W, Rashid A, Akhter P. 2010. Gamma shielding by aluminum (Al-shielder manual). Technical report. Pakistan Institute of Nuclear Science and Technology. 